\title{
ESCORÇO SOBRE A FIGURA DO ATENTADO COM BASE NO PRINCÍPIO DO APROVEITAMENTO DE MEIOS
}

\section{FORESHORTEING OF THE FIGURE OF THE ATENTADO BASED ON THE USAGE OF MEANS PRINCIPLE}

\section{Eduardo de Avelar Lamy ${ }^{1}$ Eduardo Passold Reis ${ }^{2}$}

Resumo: Com o Código de Processo Civil de 2015, o atentado deixou de ser tratado como procedimento cautelar. A opção legislativa prestigia respeito ao diálogo processual participativo e atribui ao instituto o caráter expresso de dever processual de conteúdo negativo. Contudo, com o fim das cautelares típicas, perdeu-se meio processual para denúncia do atentado e lócus específico para sua análise. Urge pensar em formas de sistematizar meios processuais para tratamento do tema. O princípio do aproveitamento de meios pode apontar caminhos para cuidar da questão.

Palavras-chave: Direito. Processo Civil. Comportamento processual. Atentado. Aproveitamento de meios.

Abstratct: With the 2015 Brazilian Civil Procedure Code, the atentado was no longer treated as a precautionary procedure. The legislative

1. Advogado. Professor da Universidade Federal de Santa Catarina nos cursos de graduação e pós-graduação. Pós-Doutor em Direito pela UFPR. Doutor e Mestre em Direito pela PUC/SP. Presidente da Comissão de Conformidade e Compliance da OAB/SC. Membro da ICA, do IIDP e do IBDP. E-mail: lamy@flamy.com. Lattes: http://lattes.cnpq.br/3023155340115210

2. Magistrado membro do Poder Judiciário de Santa Catarina. Aluno do Curso de Mestrado Profissional em Direito da Universidade Federal de Santa Catarina - UFSC. Especialista em Direito e Gestão Judiciária pela Academia Judicial do Tribunal de Justiça do Estado de Santa Catarina (2012). Formador credenciado pela ENFAM - Escola Nacional de Formação e Aperfeiçoamento de Magistrados. E-mail: eduardopassoldreis@tjsc.jus.br. Lattes: http://lattes. cnpq.br/3345257600221255. 
option reveals honors the respect the participative procedural path, attributing to atentado institute the express character of procedural negative duty. However, with the end of the typical precautionary measures, an express procedural mean for denouncing the atentado and specific locus forit's analysis was lost. It is urgent to think of ways to systematize procedural means for dealing with the issue. The usage means principle may point out ways to take care of the issue.

Keywords: Law. Civil Procedure Law. Procedural behavior. Atentado. Usage os means.

\section{INTRODUÇÃO}

O Código de Processo Civil de 2015 deixou de ver a figura jurídica do atentado como procedimento cautelar (art. 879 e ss., CPC/1973). A partir da nova legislação, o instituto passou a ser visualizado como dever das partes e de todos aqueles que participam do processo (art. 77, VI, CPC/2015).

A opção legislativa, segundo este estudo que se empreende, veio revelar boa técnica e prestigiar o respeito devido ao caminho processual compartilhado pelas partes, atribuindo ao instituto do atentado o caráter expresso de dever processual. Ele está expressamente vinculado a princípios regentes da relação processual, como o contraditório e a boa-fé.

Sob enfoque pragmático, entretanto, com o fim das cautelares típicas, perdeu-se meio processual expresso para denúncia do atentado e, por conseguinte, locus específico para debate, reconhecimento e repressão de tais atos. É imperioso que se possa sistematizar meios processuais para análise dessas questões. O princípio processual do aproveitamento de meios está apto a indicar caminhos para tanto, sob premissas de efetividade, participação e segurança, além de maior adequação ao caso concreto. $\mathrm{O}$ método do estudo que ora se traz à lume é o dedutivo, e a pesquisa se desenvolve pela análise doutrinária e legislativa. 


\section{O ATENTADO NA CENA PROCESSUAL CONTEMPORÂNEA}

Constitui atentado toda inovação material em estado de fato ou de direito litigioso, em desconformidade com a ordem jurídica. São elementos básicos do conceito de atentado: a) status quo originário da situação/relação processual controvertida; b) inovação material no status litis estabelecido com consequências de ordem objetiva; c) danos decorrentes dessa inovação material; d) antijuridicidade da intervenção no estado de fato. A doutrina especializada aponta ainda como elemento essencial para ter lugar a figura jurídica do atentado a pendência de lide. Defende a doutrina clássica que, para ter lugar o atentado, é necessária a presença de lide pendente, sem o que a interferência, malgrado ilícita, é estranha ao Direito Processual (SILVA, 1990, p. 45). Recorde-se ainda que, segundo Baptista da Silva, (2009, p. 545):

O atentado é instrumento destinado a preservar o princípio da inalterabilidade da demanda que se estabelece processualmente com a angularização da relação processual decorrente da citação. O instrumento, assim, está intimamente ligado mais ou menos "duelística" do processo como um jogo, ou como uma disputa entre contendores privados, onde haverá de sagrar-se vitorioso aquele que, com habilidade e sabedoria, tenha melhor engendrado seu ataque ao adversário, ou melhor se tenha dele defendido. Nesta perspectiva, uma vez estabelecidas as posições de cada uma das partes, toda modificação porventura introduzida na demanda provocaria um desequilíbrio em suas posições e por isso haveria de ser proibida.

$\mathrm{O}$ atentado foi tratado de forma pragmática como procedimento cautelar específico nos Códigos de Processo Civil de 1939 (arts. 712 a 716, CPC/39) e de 1973 (arts. 879 a 881, CPC/73). Mas, a bem da verdade, constitui-se, em seu étimo e ontologia, mais em um ato de desconformidade ou improbidade contra o correto e esperado andamento do estado de coisas no correr de uma demanda judicial. O objeto litigioso - justamente por ser objeto de disputa entre dois ou mais interessados em sua fruição - deve ter seu estado de fato respeitado pelos contendores no Processo. Aqueles que optam e se submetem a resolver seus conflitos pela esfera da jurisdição oficial estatal devem abster-se de inovar 
no estado de fato da coisa ou do objeto sob controvérsia. Não há livre disposição ou disponibilidade sobre o objeto litigioso: as possibilidades de modificação do seu estado são restritas (v.g. art. 109, CPC/2015), e a inovação não pode causar dano nem ser desconforme à ordem jurídica. Nesse caso, haverá abuso e, via de consequência, atentado processual.

No sistema do Código revogado, que adotava um modelo mais estrito, ao consagrar tipicidade aos atos de atentado processual, a configuração do atentado se dava, basicamente, quando realizados e provados os atos de inovação previstos no art. 879 do Código de Processo Civil de 1973 (BRASIL, 1973), consoante se transcreve:

Art. 879. Comete atentado a parte que no curso do processo:

I - viola penhora, arresto, sequestro ou imissão na posse;

II - prossegue em obra embargada;

III -pratica outra qualquer inovação ilegal no estado de fato.

Com o advento do Código de Processo Civil de 2015, a tipicidade dos atos de atentado foi abolida. O legislador implementou cláusula aberta de proibição de atentado processual, encartando-o como dever processual (BRASIL, 2015):

Art. 77. Além de outros previstos neste Código, são deveres das partes, de seus procuradores e de todos aqueles que de qualquer forma participem do processo:[...]

VI - não praticar inovação ilegal no estado de fato de bem ou objeto litigioso.

Evidentemente estruturada como cláusula geral, a proibição de cometer atentado está inserida como comportamento esperado, como dever de conduta das partes e intervenientes no processo. A utilização de cláusulas gerais na legislação codificada é forma de abertura do Código às multifacetárias dinâmicas da vida cotidiana. Elas possibilitam a construção dos sentidos normativos como que por "janelas abertas para a mobilidade da vida, pontes que o ligam a outros corpos normativos mesmo os extrajurídicos - e avenidas, bem trilhadas, que o vinculam, dialeticamente, aos princípios e regras constitucionais". (MARTINS-COSTA, 1998, p. 131). 
A multiplicidade de fatos da vida não pode ser abarcada por completo pelo legislador, por mais minudente que seja. Por isso, agiu bem o legislador ao elencar possibilidades de realização do atentado de forma aberta, sem vinculação taxativa. A criatividade é, em si, uma boa coisa, mas pode ser - e muitas vezes é - usada para a implementação de fraudes. A capacidade de inovação pode ser usada para promover progresso, mas também para malabarismos astuciosos e inidôneos. $\mathrm{O}$ dia a dia no Foro demonstra a verdade da assertiva. A norma precisa estar atenta à realidade da vida para poder regê-la com sabedoria.

Por outro lado, forçoso atestar que a caracterização dos atos de atentado - agora que deixada de lado a tipificação de condutas configuradoras - nem sempre será simples. Sua implementação dependerá das circunstâncias desenhadas no feito, das evidências angariadas casuisticamente, de uma percepção acurada e um discernimento perspicaz dos operadores jurídicos. $\mathrm{O}$ ato configurador de atentado - como ato de abuso que é - será sempre um exercício disfuncional de uma posição jurídica, um exercício desconforme a premissas regentes de um sistema jurídico.

A punição judicial de atos de atentado não deixa de ter penalidade especificada em Lei - nem se poderia objetar contrariamente, porque nullapoenasine lege. $\mathrm{O}$ que se vem assentar é que, diante do emprego de técnica legislativa de cláusula aberta, a presença dos elementos configuradores do atentado e seu reconhecimento e decretação judiciais contará mais e mais com recursos à interpretação analógica e teleológica, com a fixação de padrões decisórios pela jurisprudência e com a análise de vetores sociais e axiológicos envolvidos. Nesse campo, a experiência jurídica do foro e a prática cotidiana dos julgamentos de casos, a sufragar padrões de construção judiciária de soluções, exercerão função de aporte análogo à norma positivada (cf. ZANETTI JÚNIOR, 2014, p. 105).

Com o ocaso da tipicidade para os casos de atentado processual, o enfoque passa à argumentação específica, ao atribuir valor ao contraditório qualificado e à participação dialogal, e à realização decisional 
sensível, esteada em discurso de racionalidade e correção fornecidos pelo sistema jurídico.

Apresentado sob roupagem de cláusula geral, o dever de não cometer atos de atentado está disposto textualmente pelo legislador, amoldado no art. 77, VI, CPC. Trata-se de um comportamento processual propugnado e que se pode e deve esperar das partes e de intervenientes no processo. O descumprimento da norma - ou seja, o cometimento de atentado -, será punido com restabelecimento do estado anterior e penalidades específicas dispostas na legislação.

Daqui, divisa-se que o atentado, malgrado em concreto ser ato de cariz material, é instituto especificamente do Direito Processual. É que, com seu tratamento legislativo, o que se deseja resguardar é, por exemplo, o comportamento probo dos litigantes na destinação jurisdicional da coisa, do objeto ou do direito litigioso. Procura-se assegurar o virtual equilíbrio no estado de fato quando da instauração da lide, e que não deve ser rompido por atos voluntaristas de algum dos contendores. A intenção do instituto é a de promover segurança e confiança aos litigantes e respeito ao caminho oficial e compartilhado do Processo.

O atentado existe e se configura, pois, como instituto de Direito Processual e para servir ao Processo. A justificativa e destinação eminentemente processual do instituto em voga já foi assentada por Theodoro Júnior (2008, p. 398) para quem "a tutela cautelar serve ao processo e não ao direito material da parte porque este [...] não está em jogo quando se admite a ação de atentado e pode até ser negado na sentença da ação principal". Esse também é o parecer de Silva (1990, p. 60) em monografia específica sobre o tema, concluindo que, apesar de ser ação, atitude, ato com inflexão material própria dos atos, o atentado traz efeitos e consequências diretas para o processo e é, pois, um fato processual e também um ilícito processual.

Especialmente por sua ressignificação topológica promovida pelo legislador de 2015, o dever de não cometer atentado deve ser lido sob as luzes dos princípios da boa-fé objetiva e da cooperação, e que quaisquer atos atentatórios a essas premissas podem e devem sofrer consequências temperadas de rigor. 
Ainda que não textualmente prevista na legislação revogada, a abstenção a atos de atentado já era comportamento processual esperado. Já se cuidava de, por meio da ação de atentado, regrar o comportamento das partes - buscando, pela tipificação das infrações processuais, concitar à abstenção de tais práticas. Um exemplo claro de nexo entre atentado e comportamento das partes vem da doutrina de Baptista da Silva (2009, p. 568) ao verter o atentado como "ofensa ao íntegro litispendente"(grifou-se). A pecha de "atentante", em toda assemelhada ao chicaneiro litigante de má-fé, faz ver que a origem e o desenvolvimento do instituto estão esteados em profundos vetores axiológicos, éticos e metajurídicos.

Ao cuidar de temas relacionados à litigância de má-fé e lealdade processual, em obra específica, Iocohama (2009) classifica os atos de atentado como atos ofensivos à boa-fé processual exigida de todos os que litigam em juízo. Afirma, com referências ao CPC/1973, que "o atentado, nos termos do art. 879 do CPC também tem natureza sancionatória voltada à lealdade processual, bastando notar o que reza o art. 881 do CPC, ao retratar as consequências de sua procedência" (IOCOHAMA, 2009, p. 261). Na mesma senda, Milman (2009, p. 210-211) assenta que "o atentado configura ilícito processual visto que é fato contrário ao direito que ocorre no curso do processo, importando na prática de ato positivo ou omissivo em desacordo com as normas procedimentais".

Se mesmo sob a égide da legislação anterior, quando era previsto em procedimento cautelar específico, em apartado das linhas gerais acerca de deveres das partes e dos provimentos acerca da lealdade processual, ainda mais agora. É que a forma de classificação na novel codificação, com expressa menção a deveres processuais e com cominação de multas e sanções específicas por descumprimento de dever lealdade processual, ao lado das penas do atentado, não parece mais haver dúvida que se está sim diante de ato relacionado a uma postura ética, a um comportamento esperado e exigível das partes e intervenientes no processo.

Em reforço, observa-se que o legislador de 2015 - em singular avanço ao de outrora- preconiza que o atentado dará lugar ao retorno do estado de coisas à situação anterior à sua ocorrência (art. 77, §7, $\mathrm{CPC})$, 
concomitante à responsabilização da parte por seu ato de improbidade processual (art. 77, $\S 2^{\circ}, \mathrm{CPC}$ ).

Ao atribuir dever ao Juiz de providenciar o retorno do estado de coisas ao anterior ao da prática do atentado, alvitrando à jurisdição o uso de técnicas processuais adequadas conforme a prática iníqua perpetrada; e, principalmente, ao reconhecer o atentante de forma expressa como improbus litigator, impondo-lhe sanções processuais específicas, e reconhecendo a possibilidade de reparação de danos em outras instâncias, a norma é clara a atribuir seu feixe de implementação a balizas do princípio da boa-fé objetiva - regente do comportamento das partes no processo.

Evidenciou-se, até agora, pois, que o atentado configura comportamento processual indevido; que sua configuração não se limita a fattispecies estanques; que, para seu reconhecimento, argúcia e tino são necessários ao aplicador da norma; e que sua repressão deve se dar com austeridade.

\section{O APROVEITAMENTO DE MEIOS PROCESSUAIS E A ADEQUAÇÃO DE FORMAS DE TUTELA}

Cediço que o Código de Processo Civil brasileiro de 2015 tratou de forma inovadora a tutela cautelar, em contraposição aos anteriores Códigos de 1939 e 1973. A tutela cautelar permanece presente na legislação codificada, como se pode entrever, verbi gratia, dos arts. 294, parágrafo único, 301 e 305 a 310. Mas, o novo Código deixou de prover-se de Livro específico a regrar o Processo Cautelar e, com isso, foram revogadas as ações cautelares típicas. As ações cautelares fundiram-se, pois, em técnicas cautelares.

Não é objetivo dissertar longamente sobre o tema nem sobre o acerto ou não da medida legislativa. De qualquer modo, e volvendo ao objeto deste estudo, surge a questão: com o fim da ação cautelar de atentado, procedimento típico idealizado pelo legislador de outrora para análise, reconhecimento e reparação de atos de atentado, como proceder, hoje, para denúncia desses atos? 
Para abordagem que se pretende desenvolver, é elucidativo apresentar lição de Baptista da Silva (2009, p. 566-567), para quem o atentado só é ação cautelar pelos apelos de urgência que pretende atender, mas, quanto ao mais, é ação de provimento satisfativo. Defendia o Professor gaúcho que a sentença nessa modalidade de demanda não tem cunho cautelar, pois faz coisa julgada material e também dada a eficácia da sentença nessa modalidade de demanda. Leciona que tais sentenças contam com eficácia mandamental preponderante - pois o juiz ordena o restabelecimento do estado de fato -, ladeada por eficácias condenatória - que condena ao pagamento de prejuízos advindos do atentado - e declaratória - que reconhece a existência do atentado. A posição ilustrada não é imune a críticas, mas revela caráter que se pretende explorar para firmar posição: as múltiplas eficácias da sentença da ação de atentado fazem surgir elemento sincrético nessa espécie de tutela - sincretismo este que, com vênia aos puristas, é um desafio ao formalismo exacerbado, à rigidez procedimental e à padronização típica de ações, técnicas e procedimentos. É preciso repensar a forma de exercer jurisdição e praticar o Processo Civil, valorando menos a interesses de coesão e disciplina inférteis e atentando mais acuradamente aos direitos fundamentais daqueles que necessitam da tutela jurisdicional.

Os reclamos do tempo - e de falta de tempo - da (s) cultura(s), a velocidade e a complexidade com que se moldam e movem interações sociais na modernidade líquida, a tecnologia que assombra e conduz, as ideologias políticas, e tantos mais, são elementos que influenciam diretamente a ordem jurídica, o Direito, disciplina reguladora das relações entre pessoas, e, por consequência, o Direito Processual Civil.

Novas hipóteses e situações surgem dia a dia, dificuldades inéditas, arranjos e rearranjos que reclamam solução tópica e segura pelo Poder Judiciário. A mudança de paradigmas dos problemas do "mundo da vida" faz surgir como imperiosa a mudança de paradigmas também nas soluções a esses problemas no "mundo do processo". E isso não é um truísmo. A implementação de respostas e soluções aos casos postos em pauta são a razão de ser da jurisdição. Deixar de prestar tutela efetiva 
e tempestiva, por meio de procedimento probo e seguro, deslustram a jurisdição e minam sua esfera de credibilidade social.

Diante das complexidades no cenário, também se desenham complexas as respostas aos novos problemas que surgem. Mais e mais se volverá ao sincretismo de tutelas anteriormente aludido - e em preceitos a ele relacionados como o princípio do aproveitamento de meios processuais, também denominado de princípio da fungibilidade ${ }^{3}$.

Inolvidável, aqui, o papel ressignificado da argumentação jurídica, do diálogo processual em contraditório e da construção dialética de soluções jurídicas, tendo a jurisprudência como fonte primária de Direito, ao lado da Lei. A atividade decisional deve ser precedida e coordenada com diálogo efetivo e participativo com os participantes do processo, "possibilitando a participação dos jurisdicionados [...] legitimando o exercício do poder” (ZUFELATO, 2019, p.56).

E, para essa construção de soluções jurídicas processuais, há de se atentar, como dito, aos reclamos e às exigências no campo material, aos problemas enfrentados e que demandam resposta. Não há solução processual adequada sem atentar para o caso concreto e suas especificidades. Divorciar a resposta processual da hipótese material vivenciada é semelhante ao construtor que ergue edificação ao léu, sem projeto prévio ou planejamento, ou ao caminhante que sai a passear a esmo, sem cuidar do caminho ou destino; invariavelmente, todos, o jurista, o construtor e o caminhante, terminarão perdidos, com elevados gastos de tempo e recursos e longe do que poderiam obter com um pouco de prudência, cuidado e aviso.

Cediço, pois, que o incremento de técnicas sensíveis às especificidades da hipótese enfrentada é medida que contribui para a efetividade do Processo. Daí se entrevê que a adequação de procedimentos ou flexibilização podem contribuir para tornar determinada ação ou medida mais apropriada para cuidar de dada hipótese vivenciada no campo material.

3. Sobre a evolução de nosso pensamento acerca do tema, confira-se: LAMY, Eduardo de Avelar. Aproveitamento de Meios no Processo Civil. Salvador: Editora JusPodivm, 2021, Introdução; e LAMY, Eduardo de Avelar. Princípio da Fungibilidade no Processo Civil. São Paulo: Dialética 2007. 
Mesmo sem previsão legal expressa, mas obedecidos vetores principiológicos e ordenadores do sistema jurídico em questão, pode-se cogitar de implementar alterações procedimentais em exercício de flexibilização atípica.

Apresentando o conceito de flexibilização procedimental atípica, Oliveira (2018, p. 30-31) atesta que normas processuais erigidas por meio de cláusula aberta - como aquela que rege a vedação ao atentado processual (art. 77, VI, CPC) - têm rotas procedimentais mais alargadas, abstendo-se o legislador do desenho procedimental e possibilitando aos operadores soluções mais criativas e adequadas à situação vivenciada.

Trata-se de campo fértil para erigir-se a aplicação do princípio do aproveitamento de meios. Nessa tessitura, importante assentar que a essência desse princípio é muito maior que os fins de correção de eventuais equívocos, de conversão de medidas ou de instrumentalidade das formas. Ainda que possa se prestar a tais desideratos, dependendo de circunstâncias objetivamente verificáveis, tal princípio deita raízes em solo mais profundo. Tem bases constitucionais na efetividade e na inafastabilidade da jurisdição (art. 5 $5^{\circ}$ XXXV, Constituição Federal), da promoção do devido processo legal (art. 5 , LIV, Constituição Federal) e do contraditório (art. 5, LV, Constituição Federal) (BRASIL, 1988).

A ideia-base do princípio em questão está na ductibilidade dos procedimentos, na atendibilidade de situações-problema concretas, na possibilidade de tornar medidas judiciais melhor adaptadas à realidade prática vivenciada, a torná-las mais conformes aos desafios visualizados no campo material. É uma tentativa de extrair do sistema graus maiores de potencialidade, adequando-se aos fins de tutela dos direitos e sem se prender apenas aos meios típicos previstos pelo Código (LAMY, 2021, p. 111). Haure daí íntima ligação com as ideias da adequação e adaptabilidade e da flexibilização procedimental.

$\mathrm{O}$ aproveitamento de meios tem elementos práticos para implementação, como a ausência de erro grosseiro e de má-fé e a presença de dúvida objetiva e razoável, advinda do próprio sistema, a propiciar conversão, ou interpretação permissiva. Não é intuito explorar esses aspectos aqui. O que se propugna é fazer ver que o princípio da fungibilidade 
- auxiliado pelos vetores da adequação e flexibilização procedimental - pode e deve ser usado para compreender a questão inicial e trazer lócus específico para debate de ocorrências de atentado processual, sem desorganizar o andamento da lide principal pendente.

É que o hiato criado pelo legislador com a extinção das cautelares típicas não pode causar solução de continuidade às pretensões dos prejudicados pela prática desairosa de atentado no curso da lide. A proscrição da demanda cautelar típica do texto codificado não deixa de tornar necessária a análise das ocorrências que se amoldem ao conceito de atentado. Afinal, não é por estar revogado do texto legal algum remédio ou meio jurídico que ele simplesmente deixa de existir no plano ontológico. Os institutos jurídicos existem e se mantêm por sua história, seu desenvolvimento prático e necessidade de seu uso cotidiano, pela experiência e experimentação jurídicas e judiciárias; não por constarem ou deixar de constarem em róis legislativos. O Direito e a Lei, tomada em sentido estrito, se enfeixam, conformam e comunicam um ao outro, numa relação de expressividade, iluminação, diálogo e interação, e não de mero silogismo.

A ausência de regra específica sobre o tema e a presença de cláusula aberta não tipificada nem estanque, para balizar comportamento processual de abstenção ao atentado (art. 77, VI, CPC), fazem ver que o sistema apresenta dúvida razoável sobre como se pode proceder na prática para denunciar, debater e julgar atos de atentado. E, diante da perplexidade objetiva extraída do próprio sistema, torna-se plenamente permitido o recurso à adaptabilidade, à variabilidade procedimental e ao aproveitamento de meios para prover o prejudicado de meios a remediar seus danos e a jurisdição de instrumentos a policiar o procedimento principal dos atentados promovidos pela parte atentante.

Para a correção jurisdicional de atos de atentado, mister a realização de atos de eficácia variada, como se viu, de cunho declaratório, condenatório e mandamental. Mas, como obter essas tutelas se, agora, não há mais ação de atentado? Em incidente instaurado por petição no próprio processo originário? Por ação ordinária própria em que se visa reconhecer, provar e discutir a ocorrência do atentado? Como o atentado pres- 
supõe lide pendente, seria cabível a ação cautelar preparatória do art. 305 ? Existe apenas uma resposta válida ou é viável crer, com os contributos a que se aludiu anteriormente, pensar noutras visões possíveis de solução para os problemas postos? É o que se busca responder adiante.

\section{ANÁLISE DE OUTROS MEIOS PROCESSUAIS POSSÍVEIS PARA RECONHECIMENTO DO ATENTADO}

$\mathrm{O}$ aproveitamento de meios processuais anda em sincronia com a simplificação procedimental com vistas ao acesso à Justiça e à tutela dos direitos fundamentais. O que lhe dá molde e vivacidade são as ideias de flexibilização de tipos jurídicos e de tolerância na admissão de possibilidade jurídicas oriundas e permitidas pelo próprio sistema.

Obviamente que lançar mão desse preceito não permite ingressar no arbítrio ou na informalidade: aproveitamento de meios não é cheque em branco, não é vale-tudo. Não há dúvida que os tipos e as formas processuais têm relevância fundamental na apresentação dos pleitos, no correr procedimentalizado das pretensões, na mediação equilibrada do diálogo processual, na composição reta do litígio e na entrega efetiva do objeto da tutela àquele a quem assiste razão. As formas não deixaram de ter importância no Processo Civil, mormente quando insertas em regras. Seu conteúdo tem fundamento metajurídico nas necessidades de previsibilidade e segurança, evitando-se o arbítrio e tutelando especificamente o princípio constitucional da igualdade (art. $5^{\circ}$, caput, CF).

Contudo, o respeito às formas e ao formalismo deve ter por fundamento os interesses e os anseios dos destinatários finais da norma processual, as pessoas que perseguem a tutela de direitos e interesses por intermédio dos processos judiciais. O repensar do papel das formas no Processo, refundado sob as premissas de tutela de direitos fundamentais, entretanto, não deixa de saber certo que existem limites e pressupostos elencados pela doutrina para ter lugar o recurso à flexibilização, sem que se descambe ao arbítrio ou à insegurança jurídica. Isso porque “o informalismo só pode ocorrer se atendida a finalidade jurídica primacial do processo de realização do direito material, em tempo adequa- 
do e preservados os direitos fundamentais" (ALVARO DE OLIVEIRA, 2010, p. 282).

Os meios passíveis de escolha ou adaptação são, portanto, meios jurígenos - colhidos do próprio sistema jurídico, seja por uso histórico consagrado, por práticas observadas reiteradamente, ou mesmo por praticidade no alcance dos objetivos, desde que ausentes prejuízos e ofensas a garantias constitucionais. Efetividade de tutelas e atendibilidade às necessidades vêm em primazia à tipicidade de formas. Os meios devem ser permitidos pelo Direito - não devem ser ofensivos aos princípios e sistemas jurídicos nem estranhos aos usos judiciários -, mas não necessariamente precisam estar previstos taxativamente em instrumento normativo.

Compreende-se, à luz do que foi tratado, que as cautelares típicas incidentais (não preparatórias) são meios que não foram proscritos ou proibidos do sistema jurídico processual brasileiro. Apesar de não encartadas tipicamente pelo Código, quando surgir a necessidade de tutela urgente e de natureza especificamente cautelar, e em meio incidental - mostrando inadequado o manejo de medida preparatória, pois já ajuizado o feito principal -, será plenamente possível lançar mão da medida cautelar autônoma. Não há aqui repristinação legislativa em sentido estrito - nem é o que se está a sugerir. Há apenas recurso a meio juridicamente válido para fazer frente à necessidade de tutela específica surgida no mundo dos fatos.

Propõe-se, assim, dentro de circunstâncias específicas que entrever o mundo dos fatos e a necessidade premente de tutela de direitos, um réquiem à ação cautelar autônoma incidental. A cautelar autônoma resguarda o interesse do autor, que poderá ter em demanda especificamente cautelar - com natureza urgente e rito acelerado - provimento que, se viesse disposto no curso da causa principal, somente viria para dilatar e complicar o trâmite desta - o que faria soçobrar, por vezes, tanto o pleito cautelar quanto transtornar a demanda principal.

Implementando-se a alternativa à dita medida cujo réquiem se sugere, o réu - alegado causador da situação cautelanda - tem possibilidades processuais mais francas de resposta, o que prestigia o contraditório. 
Ambas as partes ganham com um procedimento apartado com melhor qualidade e maior especificidade na eventual produção de provas que se fizer necessária e um diálogo mais focado no problema urgente que deu azo ao ajuizamento da cautelar.

Dependendo das circunstâncias fáticas, a possibilidade de uma liminar initio litis ou mesmo de uma sentença na cautelar sem aguardar o julgamento da principal podem ser muito mais eficazes aos interesses em jogo que aguardar todo o leito processual da demanda principal.

Para a própria atividade judicial, a cautelar autônoma - ainda que seja uma ação a mais - soa positiva. Ainda que se trate de nova demanda, ela tem alcance bem mais restrito e rito menos dilargado. A questão urgente a ser resolvida com medidas de cautela no curso do processo poderia ser tratada, assim, em autos próprios com tratamento mais organizado e apropriado. O feito principal continuaria normalmente seu trâmite, sem dilações, sem miríades de petições intermediárias, noticiando fatos cuja resolução se reclama urgente ou contrapondo-se a eles, sem decisões complexas e variadas, cuidando de temas surgidos apenas no correr da causa, relacionados apenas indireta e circunstancial com os pedidos e as matérias de defesa. Sugere-se que as ações, principal e cautelar, sejam apensas - ao menos enquanto não resolvida e julgada e cautelar - para conferência, documentação e inter-relação melhor elaborada.

Especificamente para o caso do atentado, cuja existência era criticada por alguns como anacrônica e obsoleta (BAPTISTA DA SILVA, 2009, p. 549), ainda sob regência da legislação anterior, defendia-se com veemência a manutenção da autonomia da medida cautelar autônoma. Doutrina especializada aduziu sobre a importância de medida autônoma para denúncia, debate e responsabilização por atos de atentado:

Em situações dessa natureza, se faz imperioso provar a inovação e seus efeitos, criando-se procedimento incidental a tal fim, com contraditório específico a permitir, inclusive, defesa plena ao atentante. Claro está que, nessas circunstâncias, não seria conveniente, sob pena de grave tumulto processual, transportar a controvérsia incidente para o processo principal. (SILVA, 1990, p. 102) 
Também fundada em critérios pragmáticos é a doutrina de Grinover (2004, p.31) para quem "essa autonomia e tipicidade muito mais se justificam pela cognição que deve ter lugar (para saber da ocorrência de alteração ilícita) e pelos atos necessários à restituição".

A implementação de caminhos processuais alternativos aos tipos expressos e às formas legisladas não permite recursos ao aleatório, às invencionices ou ao puro e simples arbítrio. $\mathrm{O}$ recurso à adaptabilidade procedimental tem como regramáter não ofender regra expressa nem estipular casuisticamente regramentos em franco confronto com a lei. $\mathrm{O}$ aproveitamento de meios, como se disse, exige dúvida objetiva haurida da interpretação do próprio sistema a permitir mais de uma alternativa viável.

A proposta deste trabalho é apresentar meios processuais possíveis para reconhecimento, discussão e reparação dos atos de atentado. Já foi exposta a possibilidade de manejo de cautelar autônoma incidental. Mas, quem alude a aproveitamento de meios, como dito, alude à tolerância. Mormente diante de clara consagração de cláusula legislativa aberta (art. 77, VI, CPC), sem ação de tipo específico a dar vazão à referida pretensão. Não havendo construção legal de tipos específicos para cuidar do problema surgido, este pode ser resolvido por mais de uma forma permitida pela legislação.

A adesão ao princípio de aproveitamento de meios processuais retira sua razão de ser da multiplicidade de formas com que os problemas se apresentam na vida cotidiana e tem sua força motriz na tentativa de ser capaz de dar cobro a esses problemas, de forma criativa e com foco na atendibilidade ao caso concreto. Daí seu enfoque no direito fundamental de busca por tutela jurisdicional justa e efetiva, entendida como uma tutela que se amolde o quanto possível, e a um só tempo, ao litígio específico e o confronte e resolva de acordo com regramentos conformadores do sistema jurídico-processual. Cuida-se de um constante balanceamento entre o particular e o geral.

Para tanto, renova-se o papel de princípios constitucionais regentes do Processo, como o do contraditório, em seus aspectos formal e material. Trata-se não apenas de bilateralidade de audiência, mas da efetiva 
participação para aposição de seus argumentos e pontos de vista, com direito a vê-los como formadores da decisão judicial final sobre o caso: não basta mais a passividade do poder ouvir; entra em cena o aspecto ativo de poder ser ouvido. Uma abertura do sistema a meios mais dialogais redundará em soluções mais próximas das necessidades das partes no caso concreto e fará realização mais bem ajustada das normas de Direito Material ao problema posto em pauta.

Por isso, a depender das circunstâncias observadas, a ação cautelar autônoma será o meio mais efetivo e reto para análise das situações de atentado. Mas nem sempre! Haverá casos em que outras soluções possíveis no sistema jurídico poderão ser implementadas com vantagem sobre a ação cautelar. Como não há, na Lei, construção de tipo, meio específico, é possível falar-se em aproveitamento de meios, em fungibilidade, sem incidir nisso em qualquer erronia jurídica ou nulidade processual. O que importa é que, argumentativamente, seja demonstrado que, na circunstância observada, uma ou outra via eleita pelo prejudicado é a mais adequada (LAMY, 2021, p. 253-256).

A denúncia da situação de atentado poderá ocorrer, por exemplo, por simples petição ajuizada no processo principal em que determinada ordem tenha sido dada ou situação jurídica construída. Essa solução pode ser viável em casos mais evidentes, de constatação ictuoculi e com esclarecimento rápido e presente. São casos em que o retorno à situação anterior pode ser abreviado, mediante determinação, ordem judicial e meios mandamentais de cumprimento. $\mathrm{O}$ pleito reparatório não chega a desenhar-se concretamente, bastando a "mandamentalidade" do preceito, a execução de ordem nos próprios autos em que a discussão é travada para restabelecer equilíbrio antes vigente.

É comum esse tipo de ocorrência no Foro, em casos de atentado. Exemplo disso é o genitor ou parente não detentor da guarda de infante que o toma consigo por alguns dias para exercer direito de visitação ou convivência e, ao cabo do termo, não o apresenta a quem de direito exerce sua guarda, estando pendente discussão judicial sobre o tema. Para esse tipo de situação, não há necessidade de implementar ação própria. A antiga ação de busca e apreensão de menor, hoje, convolou- 
-se em técnica cautelar, passível de aplicação pronta por pleito intermediário na ação principal. Se não houve ação principal em curso, então, sim, é possível demanda autônoma. Mas, havendo ação já em curso, tudo pode ser resolvido nesta. É que, na hipótese, não há prejuízos materialmente aferíveis a reclamar pronta reparação. Basta a efetividade da tutela mandamental - a devolução da criança ao seu correto local de estada - nada havendo mais a reparar ou restabelecer que o status quo da pessoa tutelada.

Propõe-se ainda outra forma de pensar a questão. Conforme o grau de destempero do atentante e as circunstâncias objetivas e consequências do atentado, é possível entrever ainda outra possibilidade de solução, que não a petição intermediária nos autos principais e tampouco a cautelar autônoma. A situação pode ser cunhada por gravidade tal que perpassa o caráter mandamental - cuja técnica poderia ser perseguida no processo principal - e mesmo o de demanda cautelar, com aspectos de mandamento e reparação imantados pela urgência e autonomia procedimental. Hipóteses em que os atos de atentado, além de transtornar os envolvidos, impliquem direitos de terceiros, ou prejudiquem a coletividade - a reclamar tutelas inibitórias ou de remoção de ilícito - podem conclamar ao uso de remédio jurídico de espectro mais lato, com atuação mais ampla e vigorosa. Nesse ponto, entende-se mesmo ser possível ajuizar ação de conhecimento, pelo procedimento comum, como ação própria para reconhecimento e punição pelo atentado, com a possibilidade de pleitear medidas de urgência antecipatórias, inibitórias ou outras, que se mostrem mais adequadas às situações concretas.

Suponha-se que o atentante, ao prosseguir em determinada obra ou serviço ou contrato, ofenda posição jurídica de seu adversário, mas vá além, causando danos ambientais, por exemplo, expelindo poluentes tóxicos em curso de água ou ofendendo a relações de vizinhança. No caso, os prejudicados com os danos ambientais ou os vizinhos podem ter danos a reclamar - e dependendo das circunstâncias tanto o causador do atentado quanto a vítima dele poderiam ter responsabilidade perante esses terceiros. $\mathrm{O}$ atentado, nesse caso, não tem efeitos limitados às partes envolvidas na discussão principal. Pela envergadura dos danos 
causados e suas consequências, terceiros tiveram direitos violados, e a ordem pública foi atingida, com possibilidade de responsabilização em outras esferas (administrativa, criminal, por exemplo).

Em hipótese tal, o manejo de um processo autônomo, com os pleitos de antecipação ou urgência necessários e possibilidade de discussão mais ampla e instrução mais dilargada, mostra melhor molde à hipótese fática tão complexa. Nesse caso, haveria uma demanda específica para retratar, provar e responsabilizar os atos de atentado, sem descurar das medidas de urgência para sua cessação. Terceiros poderiam habilitar-se como interessados na demanda para o acertamento de seus danos. A participação se daria de modo mais pleno e efetivo que numa ação cautelar interpartes ou que na simples menção do fato no processo principal. E o postulado de Responsabilidade Civil, de responsabilização na medida da extensão do dano- art. 944, Código Civil (BRASIL, 2002) -, seria privilegiado por meio de uma instrução plenária, com participação ampla e diferenciados meios de prova.

Demonstra-se, pois, que a opção legislativa de prever o atentado processual como cláusula aberta privilegia a possibilidade de seu reconhecimento por várias formas possíveis e permitidas pela legislação processual, denotando-se, assim, campo fértil para aplicação do princípio do aproveitamento de meios no Processo Civil.

Não há caminho unívoco e exclusivo para denúncia e apreciação de atos de atentado. E a extinção de previsão legislativa de demanda específica não deixou o sistema sem possibilidades, ao contrário. Novas formas de debate são possíveis para as ocorrências de atentado, com base no aproveitamento de meios, e iluminadas pelos vetores de adequação e flexibilidade procedimental.

Em resposta aos questionamentos outrora lançados na busca de um mais elaborado exame da questão, tem-se que o dever de não cometer atentado é comportamento processual exigível e vigente. Para sua obediência, cumprimento e reparação, o princípio da fungibilidade e as técnicas de flexibilização procedimental são guias e apresentam ferramentas, formas instrumentais de pleitear. $\mathrm{O}$ uso dessas formas será justificado argumentativamente e de acordo com os direitos materiais 
violados, cuja tutela se persegue, além das circunstâncias fáticas envolvidas na hipótese. Destaca-se que são viáveis e possíveis, pois, tanto a cautelar autônoma incidental, como o peticionamento nos autos principais, e ainda o ajuizamento de ação própria, de cunho ordinário, e com pleitos de urgência ou antecipatórios. Atendendo às especificidades que se desenharem no plano fático, o princípio do aproveitamento de meios abona a adoção de qualquer uma das técnicas instrumentais de acionamento da jurisdição.

\section{CONCLUSÃO}

Ofende a boa ordem do processo judicial e o espírito de decoro e boa-fé que deve nortear o litigante em juízo aquele que pratica atentado processual. Inovar em estado de fato sobre objeto ou direito litigioso, de forma antijurídica, é conduta que merece reprimenda. $\mathrm{O}$ instituto do atentado foi aposto taxativamente pelo Código de Processo Civil de 2015 como dever de conduta das partes e intervenientes no processo. Trata-se de um mandamento negativo, de abstenção, que visa tutelar o estado de coisas da lide pendente; é, pois, instituto do campo do Direito Processual. A ocorrência de atentado deve ensejar ordem judicial que venha ensejar restabelecimento do estado anterior e determinação de punição por ato de improbidade processual, nomeadamente, ato atentatório à dignidade da justiça. Por isso, o atentado, hoje, amolda-se ao conceito de contempt of court.

Como disposto em cláusula aberta no novo Código de Processo, a configuração do atentado e sua denúncia no processo judicial passa induvidosamente por um processo de construção, fundado em argumentação sensível e produção de prova específica para analisar se a conduta perpetrada pode ou não ser considerada atentado. A sindicância procedimental do atentado deve ser prévia à punição e deve preceder procedimento apropriado - ainda que de natureza sumarizada -, sugerindo-se medida cautelar, mantendo-se tradição das legislações codificadas anteriores. 
Com o fim das cautelares típicas, objetiva-se que o princípio do aproveitamento de meios, plasmado pela ideia de flexibilização e adaptabilidade, possa apontar caminho para o modus operandi de denunciar, conhecer de questões, produzir provas, reparar danos e reprimir condutas de atentado processual.

Entende-se ser possível o ajuizamento de medida cautelar autônoma - malgrado não tipificada em Lei, mas viável pelo uso e compreendida dentre os meios dispostos pelo sistema jurídico - para o desiderato perseguido. A ação autônoma, de natureza cautelar urgente, com eficácia mandamental e condenatória, correria de forma incidente ao feito principal. O procedimento principal ficaria, assim, resguardado de discussões diversas de sua causa de pedir e teses a analisar, sem maiores dilações. E haveria meio procedimental específico, elaborado com fim adequado a analisar unicamente a prática do atentado com discussão e instrução restrita, ganhando ambos os feitos - o principal e o cautelar relacionado - em organização e efetividade.

Objetiva-se ainda que, a depender do suporte fático da hipótese versada, o atentado poderá ser conhecido, denunciado e enfrentado ainda de outras maneiras. Com o fim da "ação própria" prevista na legislação anterior, e presente cláusula aberta para assentar o tema na Lei Processual vigente, o sistema ganha abertura, o que permite erigir possibilidades juridicamente viáveis para análise da existência ou não de atentado.

Em questões simples, em que o objeto ou direito litigioso sofreu dano menos intenso, de baixa complexidade ou de simples evidenciação, a cautelar autônoma será substituída com vantagem pelo peticionamento com pleito específico nos autos da ação principal, cujo equilíbrio de forças foi maculado pelo atentado.

Em contrapartida, ocorrerão hipóteses sobremaneira complexas, cuja especificidade escapará à análise no feito principal e mesmo às possibilidades oferecidas pela demanda cautelar autônoma. Casos em que o atentado gera danos não somente inter-partes, mas para terceiros ou ofender outras searas de responsabilização - como o caso em que o atentado configure também uma infração penal - podem, dependendo de circunstâncias especiais, ter de ser tratados de modo mais lato e cui- 
dadoso, o que somente pode ser propiciado por ação própria, de rito ordinário, pelo procedimento comum, com possibilidade de antecipar-se efeitos da tutela jurisdicional.

A conclusão é que o princípio do aproveitamento de meios tem amplo espectro de utilização no tema estudado. A atendibilidade ao caso concreto, a possibilidade de flexibilização procedimental e a análise da tutela adequada que clama o direito material ofendido são aspectos essenciais ao se considerar o tratamento processual da cláusula aberta prevista no art. 77, VI, do Código de Processo Civil, com vistas à reparação de atos de atentado e à promoção dos institutos da boa-fé objetiva e da lealdade processual.

\section{REFERÊNCIAS}

ALVARO DE OLIVEIRA, Carlos Alberto. Do formalismo no processo civil: proposta de um formalismo-valorativo. 4. ed. rev. atual. aum. São Paulo: Saraiva, 2010.

BAPTISTA DA SILVA, Ovidio. Do processo cautelar. Rio de Janeiro: Forense, 2009.

BRASIL. Constituição da República Federativa do Brasil (1988) (texto compilado). Presidência da República. Casa Civil - Subchefia para Assuntos Jurídicos. Brasília, DF. Disponível em: http://planalto. gov.br. Acesso em: 20 maio 2021.

BRASIL. Código Civil. (2002). Lei 10.406, de 10 de janeiro de 2002 (texto compilado). Presidência da República. Casa Civil - Subchefia para Assuntos Jurídicos. Brasília, DF. Disponível em: http://planalto. gov.br. Acesso em: 25 maio 2021.

BRASIL. Código de Processo Civil (1973). Lei 5.869, de 11-01-1973 (texto compilado). Presidência da República. Casa Civil - Subchefia para Assuntos Jurídicos. Brasília, DF. Disponível em: http://planalto. gov.br. Acesso em: 25 maio 2021.

BRASIL. Código de Processo Civil (2015). Lei 13.105, de 16-03-2015. (texto compilado). Presidência da República. Casa Civil - Subchefia 
para Assuntos Jurídicos. Brasília, DF. Disponível em: http://planalto. gov.br. Acesso em: 20 maio 2021.

GRINOVER, Ada Pellegrini. Atentado - configuração, objeto e natureza. Revista Síntese de Direito Civil e Processual Civil, vol. 5, n. 30, jul./ago./2004. Porto Alegre: Síntese, 2004.

IOCOHAMA, Celso Hiroshi. Litigância de má-fé e lealdade processual. (Ano 2006), $1^{\mathrm{a}}$ reimpr. Curitiba: Juruá, 2009.

LAMY, Eduardo de Avelar. Aproveitamento de meios no processo civil. Salvador: Editora JusPodivm, 2021.

LAMY, Eduardo de Avelar. Tutela provisória. São Paulo: Atlas, 2018.

LAMY, Eduardo de Avelar. Princípio da fungibilidade no processo civil. São Paulo: Dialética, 2007.

MARTINS COSTA, Judith Hofmeister. O direito privado como um "sistema em construção": as cláusulas gerais no Projeto do Código Civil Brasileiro. Revista da Faculdade de Direito da UFRGS. n. 15, Porto Alegre: UFRGS/Síntese, 1998.

MILMAN, Fabio. Improbidade processual: comportamento das partes e de seus procuradores no processo civil. Rio de Janeiro: Forense, 2009.

OLIVEIRA, Paulo Mendes de. Segurança Jurídica e Processo: da rigidez à flexibilização procedimental. São Paulo: Thomson Reuters Brasil, 2018.

SILVA, Agathe E. Schmidt da. Do atentado. Porto Alegre: Livraria do Advogado, 1990.

THEODORO JÚNIOR, Humberto. Processo cautelar. 24. ed. rev. e atual. São Paulo: Livraria e Editora Universitária de Direito - LEUD, 2008. 
ZANETTI JÚNIOR, Hermes. A constitucionalização do processo: o modelo constitucional da justiça brasileira e as relações entre processo e Constituição. 2. ed. rev. ampl. alt. São Paulo: Atlas, 2014.

ZUFELATO, Camilo. Contraditório e vedação às decisões-surpresa no processo civil brasileiro. Coleção: Direitos Fundamentais e acesso à justiça no estado constitucional de direito em crise. Gregório Assagra de Almeida. (coord.). Belo Horizonte: editora D’Plácido, 2019.

Recebido em: 28/06/2021 Aprovado em: 05/07/2021 